\title{
Urdu Dili ile Yazılan Seyahatnamelerde Cuma Selamlığı
}

\section{The Ceremony of the Selamlik in the Travelogues Written in Urdu}

\author{
Arzu Çiftsüren* (i)
}

Dr. Öğr. Üyesi, İstanbul Üniversitesi, Edebiyat Fakültesi, Doğu Dilleri ve Edebiyatları Bölümü, İstanbul, Türkiye

\section{ORCID: A.Ç. 0000-0003-0590-348X}

Sorumlu yazar/Corresponding author: Arzu Çiftsüren,

Istanbul Üniversitesi, Edebiyat Fakültesi, Doğu Dilleri ve Edebiyatları Bölümü, İstanbul, Türkiye E-posta/E-mail: asuren@istanbul.edu.tr

Başvuru/Submitted: 08.09 .2020 Revizyon Talebi/Revision Requested: 28.11.2020

Son Revizyon/Last Revision Received: 20.12.2020

Kabul/Accepted: 27.12 .2020

\section{Atıf/Citation:}

Ciftsuren, Arzu. "Urdu Dili ile Yazılan Seyahatnamelerde Cuma Selamlığı." Tarih Dergisi - Turkish Journal of History, 73 (2021): 117-129. https://doi.org/10.26650/iutd.788745

\section{öz}

Hindistan Pakistan Alt Kıtası ile Osmanlı Türklerinin ilişkileri özellikle 187778 Osmanlı-Rus Savaşı'ndan sonra farklı bir seyir izlemiştir. II. Abdülhamid dönemine İslam Birliği çerçevesinde Alt Kıtada faaliyetlerin artırıldığı, İslam ülkeleri arasında en fazla desteği de bu coğrafyadan geldiği söylenebilir. Urdu dilinde seyahatname yazılmaya başlamasından çok kısa bir süre sonra ortaya Osmanlı topraklarını özellikle İstanbul'u konu olan pek çok seyahatname çıkmıştır. Bu seyahatnamelerde Osmanlı Türklerine ilişkin siyasi, sosyal ve kültürel pek çok alanda bilgi verilmiştir. Osmanlı'da padişah ile halkın yakınlaşmasını sağlayan törenlerden biri olan Cuma Selamlığı Urdu dili ile yazılan seyahatnamelerde bütün görkemi ve ihtişamıyla akis bulmuştur.

Anahtar sözcükler: Hindistan Pakistan Alt Kıtası, Il. Abdülhamid, Urdu dili, Seyahatname, Cuma Selamlığı

\section{ABSTRACT}

The relations between Indo Pak Subcontinent and Ottoman Empire followed a different direction after the Russo-Turkish War of 1877-1878. Abdulhamid II carried out many activities with the idea of Pan Islamism and as a result of these activites different kinds of supports reached the Ottoman Turks from the subcontinent more than the other Muslim geographies. Only few years later of starting travelogue in Urdu literature, travelelogues on Turkey have been written. In these travelogues social, culturel and politikal informations about Ottoman have been given. Selamlik ceremony which is one of the ceremonies that makes Sultan and people closer was reflected with all its splendor.

Keywords: Indo Pak subcontinent, Abdulhamid II, Urdu Language, Travelogue, the Selamlik ceremony 


\section{Extended Abstract}

In addition to being literary genre, travelogues are closely related to disciplines of history and geography. Like any other philosophical view and art-work, travelogues also carry many pros and cons. One common critique of travelogues is that they are written only from the author's point of view whereby the author's biases and preferences cannot be completely disregarded. It is also observed that most travel writers exaggerate in order to influence and persuade their readers. Consequently, the information contained cannot be guaranteed to be reliable because of the authors' biases and exaggerations. Nevertheless, travel writing still presents vast information merged into conceptual thoughts specific to the country under observation, not only from the stand point of geography but also from the point of view of social structure.

The first travelogue in Urdu was written by Yousuf Kambal Posh in 1837 after his adventurous trip to London. Thereafter, travelogues about Turkey and Turks were written by other writers in Urdu. It is pertinent to mention that the travelers from the Indian subcontinent also made efforts to convey their thoughts through travelogues and visited Turkey especially during the reign of Abdulhamid II. Travelogues of this period narrated information about Turkey in various domains, from politics to culture, from education to everyday life.

The travelogues of this era were deeply influenced by the ideas of Panislamism, first conceived by Abdulhamid II, linking Turkey with the South Asian subcontinent. After 1857, Muslims from the Subcontinent turned their faces to the Ottoman Empire and tried to provide financial and moral support to their Turkish brothers to whom they were connected via the caliphate bond. In the first phase of these travelogues, authors writing travelogues about Turkey in Urdu were mostly prominent educationalists and jurists from the Indian subcontinent. One of the main motives that brought them to the Ottoman lands was to inscribe the metaphysical forces of Istanbul, to observe and then share academic views with their own people, creating public about the Turks while at the same time ensuring coordination amongst the Islamic countries. Examining the travelogues of Shibli Naumani, Abdurrahman Amritsari and Sheikh Abdulqadir, we find that detailed information about the Turks and the sociocultural state of affairs in the Ottoman Empire is provided.

The Selamlik ceremony, for example, was of great importance to these foreign travelers travelling from the sub-continent. In these travelogues, the authors wrote that although the Selamlik ceremony had a social aspect that enabled the Sultan and the people to get closer, it also enabled the Sultan to inspect the current situation of the military. They also explain that, being Muslims, they are proud to comprehend the glory of the Ottoman Empire at this very ceremony. Some of these travelers from the sub-continent were bestowed "Tamgha-e Majidi" by then Khalifa of time Abdulhamid II. 
Hindistan Pakistan Alt Kıtasının İslâm sonrası Orta Asya Türkleri ile münasebetleri Gazne Devleti hükümdarı Mahmûd'un Hindistan seferlerine kadar gitse de, Osmanlı Türkleri ile ilk temasları İstanbul'un fethinden sonra XV. yüzyılda olmuştur. Behmenî Devleti Sultanı Mehmet Şâh veziri Hoca İmâdü'd-dîn Mahmud Gavan'1 İstanbul'un fethinden dolayı Fatih Sultan Mehmet'i tebrik için İstanbul'a elçi göndermiş ve böylece siyasi ilişkiler başlamıştır.

Vasco de Gama komutasındaki Portekiz gemilerinin Ümit Burnu'nu geçerek 1498 yılında Hindistan'ın güney kıyılarına ulaşması ile ekonomik düzen değişmiş, o zamana kadar Türkistan, Anadolu kervan yolu üzerinden ve Kizıldeniz'den yapılan ticaret Portekizliler lehine yön değişstirmiştir. Bu süreçte Hindistan'da hüküm sürmekte olan Gucerat Sultanlığ1 Portekizlilere karşı Osmanlı'dan yardım istemiş ve böylece Osmanlı Devleti tarafından Hindistan'a çeşitli süreçlerle Hint deniz seferleri düzenlenmiştir. Bu seferlerde Portekizlilere karşı mutlak bir üstünlük sağlanamazken 1556 yılında bölgeye giden donanmanın başında bulunan Seydi Ali Reis İstanbul'a dönünce bir Türkün Hindistan Pakistan Alt Kıtası ile ilgili doğrudan yazdığı ve aynı zamanda Türk dili ile yazılmış ilk seyahatname olan Mir'atü'lMemâlik adlı eseri yazmıştır.

Geniş topraklara sahip olan Hindistan Pakistan Alt Kıtası zaten tarih boyu siyasi birlikten mahrum olmuş, çeşitli bölgelerinin farklı devletlerce yönetilmesi ve en son İngilizlerin bölge üzerindeki faaliyetleriyle artık iyice çıkmaza girmiştir. 1857 Büyük Sipahi ayaklanması sonucu Türk soylu Babür Devletinin (1526-1858) başkenti olan Delhi'nin İngilizler tarafindan ele geçirilmesi sonucu Babür Devleti yıkılmış, yönetim İngilizlere geçmiştir. Böylece İngiliz sömürgesi olarak siyasi, kültürel ve dini anlamda hareket alanları kısıtlanmış, resmi olarak dillerini dahi kullanamama noktasına gelmişlerdir. Artık bu tarihten sonra İngiltere'nin sömürü ülkesi durumunda yaşamaya başlayan Alt Kıtada bu esaretten kurtuluş mücadelesi başlayacaktır.

Bu kurtuluş mücadelesi kapsamında rol model alınan Osmanlı'ya olan alaka da artmış, toplumun tüm kesimlerinden zor bir süreç yaşamakta olan Osmanlı için çeşitli vesilelerle yardım toplanmaya başlanmıştır. Hindistan Pakistan Müslümanları ile Osmanlı Türklerinin ilişkileri özellikle Sırp İsyanı ve 93 Harbinden sonraki süreçte farklı bir seyir izlemiştir. Hilafet merkezli olarak bağlı oldukları, Batının esaretine girmemiş son büyük İslam devleti olan Osmanlı Devleti'nin karşı karşıya kaldı̆̆ı sıkıntılı süreçlerde maddi manevi Osmanlı'nın yanında olmuşlardır. Trablusgarp Savaşı, Balkan Savaşları ve Milli Mücadele dönemlerinde Osmanlı’ya en fazla yardım Alt Kıta Müslümanlarından yapılmıştır.

Alt kıtada Urdu dili ile seyahatname türünde eserler verilmeye başlandıktan çok kısa bir süre sonra özellikle İstanbul ile ilgili seyahatnameler peşi sıra yazılmıştır. Bunda hadis-i şerife konu olan İslam'ın en büyük merkezlerinden İstanbul'u görmek arzusunun yanı sıra özellikle II. Abdülhamid döneminde Alt Kıtada izlenen politikanın da etkisi vardır. II. 
Abdülhamid'in Panislamizm siyaseti özellikle sömürge altındaki İslâm ülkelerinde kabul görmüş, oradaki milli kimliklerin gelişmesinde önemli rol oynamıştır. Sömürü durumundaki Müslüman devletlere maddi ve siyasi destek sağlamaya çalışan II. Abdülhamid din adamları ve devlet elçileri vasıtasıyla bu devletlerin İslâm Birliği ve Osmanlı etrafında birleşmelerini temin etmeye çalışmıştır. Bu doğrultuda Mısır ve Hindistan gibi devletleri sömürgesi altında bulunduran İngiltere ile karşı karşıya gelen II. Abdülhamid, izlediği siyaset ile Müslüman halkı uyandırmış, İngiltere'nin sömürgeci ilerleyişini sekteye uğratmıştır. Nitekim hatıratında bunu şu şekilde ifade etmektedir:

“Ingilizler Asya'da yüz elli milyon Müslüman'ı idareleri altında tutuyorlardl. Bu Müslümanlar üzerinde Hilafetin büyük nüfuzu vardı. Bunları bildiğim için İngilizleri kuşkulandırmadan, her ihtimale karşı seyitler, şeyhler, dervişler gönderip Asya'daki Müslümanları hilafete manen bağlamaya hususî itina gösteriyordum. Buharalı Şeyh Süleyman Efendi'nin Rusya'daki Müslümanlar arasında yaptığl hizmetleri bilhassa şükranla yâd ederim. Bunun Ingilizlerle münasebetlerimizde çok faydasını gördüm. Hindistan'daki umumî valileri, oradaki Müslümanların Osmanlı Devleti'yle yakından ilgilendiklerini gördükçe, hükümetlerine, Osmanlılarla iyi geçinmelerini yazlyorlar ve böylece bizim işlerimiz bir nebze kolaylaşmış oluyordu."

II. Abdülhamid döneminde 1882'den itibaren Osmanlı temsilciliklerinin sayısında bir artış olmuştur. Özellikle Hindistan'ın Müslüman nüfuslu beldelerinde bu artış yoğun olarak göze çarpmaktadır. Bu yıllarda temsilcilik açma girişiminin başında Karaçi gelmekteydi. Bombay, Kalküta, Madras, Kolombo gibi ticaret merkezlerinde de fahri şehbenderlikler açılmıştır. Fahri şehbenderlerin, Osmanlı taraftarı, şerefli, zengin ve ahali arasında ağırlığı olan ailelerden olmalarına dikkat edilmiş, böylece Müslüman halk ile halifelik payesini kullanarak yakın olunmak istenmiştir. ${ }^{2}$

II. Abdülhamid'in Alt Kıtada izlediği diğer bir politika ise Osmanlı Devleti'ne temsilcilikler vasıtasıyla iane toplanıldığında, bağışta bulunan kimselere taltifen madalyalar göndermesidir. Osmanlı hükümetince kurulan Bombay başşehbenderinin kurduğu komisyon bir yandan yardımları düzenlerken, bir yandan da verilecek madalyaları organize ediyordu. Nitekim II. Abdülhamid'in bağıșta bulunanlara Osmanlı Hükümeti'nin takdir ve teşekkürlerini nişanlarla, madalyalarla ifade etmesi siyaseti de Hindistan Pakistan Alt Kitası Müslümanlarını teşvikte oldukça önemli bir rol oynamıştır. ${ }^{3}$

Hicaz Demiryolu Projesi de II. Abdülhamid'in Müslüman nüfus üzerinde saygınlığının ve otoritesinin artmasına vesile olmuştur.

İsmet Bozdağ, II. Abdülhamid'in Hatıra Defteri, İstanbul, Kervan Yayınları, İstanbul 1975, s.75.

Cezmi Eraslan, II. Abdülhamid ve İslâm Birliği, Ötüken Yayınları, İstanbul 1992, s. 315-330

Azmi Özcan, Pan-İslamizm Osmanlı Devleti Hindistan Müslümanlarl ve Íngiltere 1877-1924, Türkiye Diyanet Vakfi Yayınları, Ankara 1997, s. 144-149. 
Bütün bu etkenler Alt Kıta Müslümanlarının Osmanlı'ya bağlılıklarını artırmaktaydı. Böylece çeşitli vesilelerle Alt Kıtanın ileri gelen kişileri Osmanlı topraklarına gelerek, buradaki gözlemlerini, savaşın durumunu Alt Kıtanın çeşitli merkezlerindeki gazetelerde yayımlamışlardır. Aynı zamanda bu gözlemlerini seyahatname olarak da kaleme almışlardır. Türklerle ilgili yazılmış ilk seyahatname 1885 yılında Nevvab Muhammed Ömer Han tarafından kaleme alınan “Aine-i Freng” (Batı'nın Aynası) ${ }^{4}$ adlı eser olsa da bu eser sadece İstanbul ile ilgili genel bilgiler içermektedir. Urdu dili ile yazılan ve Osmanlı'nın içinde bulunduğu durumla ilgili bilgiler veren ilk kapsamlı seyahatname Alt Kıtanın ünlü âlimi Şiblî Numanî tarafından 1892 yılında yaptığı seyahatine dair gözlemlerini anlattığı "Anadolu, Suriye, Mısır Seyahatnamesi"dir. ${ }^{5}$ II. Abdülhamid'in tahtta olduğu dönemde yazılan bu seyahatnamede dönemle ilgili sosyal, kültürel ve siyasi pek çok bilgi bulunur. II. Abdülhamid ve Plevne kahramanı Gazi Osman Paşa ile tanışan Şiblî her ikisi için de birer şiir yazmıştır. Cuma selamlığıyla ilgili de detaylı bilgi vermiştir. Selamlık merasiminin amacı ile ilgili selamlık merasimi âdetinin uzun süredir yapıldığını ve devlet protokolünün bir parçası haline geldiğini, bu merasimde sadece padişahın haşmeti ve azametinin gösterilmesinin amaçlanmadığını aksine bununla her hafta ordunun önemli bir bölümünün teftişinin yapılmış olduğunu ifade eder. Ayrıca devlet merkezinde ve merkezin çevresinde kalan askerî birliklerin hepsi bu yolla senede birkaç kere de olsa Sultanın kontrolünden geçerken ordunun durumunu bir ölçüde öğrenmiş olduğunu askerlerin gönlünde ise Padişah’a karşı duyulan sayg1 ve bağlılık duygularının arttı̆̆ını belirtmektedir. ${ }^{6}$

Cuma Selamlığı, Osmanlı döneminde hükümdarların halka açık bir camide Cuma namazı kılması ve bu esnada yapılan merasime denmektedir. 1453 yılından 1924 yılına değin padişahlar İstanbul'da kaldıkları sürece bu töreni mutlaka yaparlardı. Sadece siyasi ve sosyal yönüyle değil, hukuki ve kültürel açıdan da önem taşımaktadır. Cuma selamlığı sırasında ilmî, askerî ve mülkî erkân üniformalarıyla hazır bulunur, Cuma namazı hangi camide kılınacaksa yol boyu sağlı sollu dizilen askerler merasime eşlik ederlerdi. Yabancı seyyahlar bu töreni mutlaka izlemek isterlerdi. ${ }^{7}$

Alt Kıtadan gelen seyyahlar için ise Cuma Selamlığına iştirak etmek Hilafet merkezi Osmanlı'nın azametini görmek ve padişahla aynı camide namaz kılabilmek ayrı bir gurur vesilesi olmuştur. Nitekim Şiblî yukarıda adı geçen seyahatnamesinde selamlık ile ilgili şu genel bilgileri verir:

"Sultan genellikle sarayından dışarı çıkmaz. Sadece her hafta Cuma namazı kılmak için camiye gelir ve burada namaz kılınıp bittikten sonra "Selamlı" denilen merasim

4 Navvab Omar Han, Safarnama-i Aina-i Frang, Matba Munşi Naval Kişor, Lakhnov.

5 Şiblî Numanî, Anadolu-Suriye-Mısır Seyahatnamesi (Tercüme: Yusuf Karaca), Risale Yayınları, İstanbul 2002.

6 Şiblî Numanî, a.g.e, s.114.

7 Mehmet İpşirli, “Cuma Selamlığı”, Türkiye Diyanet Vakfi İslam Ansiklopedisi (DİA), VIII, İstanbul 1993, s. $90-92$. 
yerine getirilir. Gerçekten o anda meydana gelen ihtişami, heybet ve azameti dille veya kalemle tasvir etmek pek zordur. Ayda 4 kere veya senede 48 kere icra edildiği için basit bir olay gibi tahmin edilebilecek olan bu gösteriye daima çok sayıda insan katılmaktadır. Yerlerin almadığ insanlar ă̆açlara ve diğer insanların omuzlarına tırmanarak gösteriyi seyretmektedir. Istanbul'u gezmeye gelen turistler ve ileri gelen devlet adamlart bu firsatı hiçbir zaman elden kaçırmıyorlar, mutlaka töreni seyretmeye geliyorlar. Padişah ve yanındaki heyetinin güzergâhının üzerinde yüksekçe bir teras vardır. Muayede salonunun önüne gelen bu terasa bilet alınarak çıkılır."

Padişahın camiye gelmesiyle yaşananları Şiblî Numanî şöyle anlatmaktadır:

“... Türklerin milli bir narası halini alan "Padişahım çok yaşa” çı̆̆lı̆̆ her tarafi inletti. Bu nara arka arkaya üç kere yükseldi. Sultanın arabası caminin tam önüne ulaştı ama her tarafi inleten naralar hala dinmemişti. Tam bu sırada padişahın gelişini beklemekte olan müezzin "Allahu Ekber" nidasını yükseltti. Bu iki ses birleşince kalplerde derin etki yapıyordu."

Daha önce hiç görmediği bu manzara karşısında kendinden geçtiğini ve içinde tarif edilmez bir coşku hissettiğini belirten Şiblî Numanî, padişahın üstü açık bir arabayla geldiğini ifade edip namaz kılacağı bölümü şöyle anlatmaktadır:

“Sultan II. Abdülhamid'in yaptırdiğ bu Yıldız Hamidiye Camii’nin ana yapısının kenarları iki katlı özel mekânlar olarak yapılmıştır. Sol taraftaki ikinci kat özel olarak Sultan'in namaz kılması için ayrılmış yerdir. Sultan arabadan inerek birkaç basamaklı mermer merdivenlerden çıktı ve kendine has yere girdi. Oraya girmesiyle birlikte atlastan yapılmış perdeler indirildi. ${ }^{\prime 10}$

Hatibin Abdülhamid için yaptığı Arapça duanın ardından yoğun bir duygu seline kapıldığını ve gözünden sürekli yaşlar aktığını anlatan Şiblî Numanî, Cuma hutbesinin adabına ve caminin huzuruna aykırı olduğunu düşündüğü durumu eleştirel bir şekilde şöyle anlatmaktadır:

“... Ellerinde dilekçeleri ve padişahtan bir taklm istekleri olan on beş yirmi kişi hep birlikte ayağa kalktt. Bu insanlar Sultan'a doğru ellerini uzatarak dua ediyor ve dilekçelerini takdim ediyorlardl. Arz beyi denen, bu tür dilekçeleri Sultana ulaştırmakla görevli kişi dilekçe kâğıtlarını topladı. Bazılarının Sultan'a doğru elleriyle işaret ederek yere eğildiğini ve ellerini yere dokundurduktan sonra o eli öptüklerini gördüm."

Namaz sonrası tören ise Şiblî Numanî'nin seyahatnamesinde şöyle anlatılmaktadır:

“... Namaz kildıktan sonra herkes dişarı çıkıp gidince Sultan kendine ait olan salonlu bölmeden çıktı ve selamlama merasimini rahatça seyredebildiği ve Sultan 'in kendisini hiç kimsenin görmediği merdiven başına gelip oturdu. Ordu komutanlarl ve paşalar avlunun să̆ tarafinda sıra sıra dizilmiş ayakta duruyorlardı...

8 Şiblî Numanî, a.g.e, s.110.

9 Şiblî Numanî, a.g.e, s.111.

10 Şiblî Numanî, a.g.e, s.111.

11 Şiblî Numanî, a.g.e, s.112. 
Biraz sonra askerlerin geçidi başladı. Sultan sarayından camiye kadar aşağı doğru inişli geniş bir cadde vardl. Geniş alanda hilal şeklinde dizilerek ayakta duran askerler sarayın önünden geçerek caminin avlu ana kapısından içeri giriyor padişahı selamlayarak diğer kapıdan da çıkıp gidiyorlardı. Safların sıralanışı; süvari, piyade, denizci, karacı, topçu, Türk, Kürt, Arap. Ayrı ayrı sıralanmış haldeydiler. Uygun adımla ve tertipli yürüyüşle ateşli silahlar taşıyan değiş̧ik ve güzel görünümlü merasim bölükleri askerlerin arka arkaya birlikler halinde gelişleri, Sultan'a bağgllıklarını ve vefakârlıklarını arz ederek önünden geçişleri öyle zevkli ve insana heyecan veren bir manzaraydı ki hiçbir şekilde insan bunu hakkıyla anlatamaz... Üç saat boyunca bu asker denizi dalgalandı durdu. Aşağl yukarl on bin asker geçti. Merasimin sonuna doğru Sultan'ın iki şehzadesi geldi. Gönülleri coşturan muhteşem bir görüntü vardl. 10-15 yaşlarında olmalarına rağmen öyle bir ciddiyet ve vakarla atlara binmişlerdi ve yüzlerinde öyle bir cesaret ve ihtişam gözüküyordu ki anlatılamaz." 12

Şiblî Numanî, Sultan'ın eşkâli ile ilgili şunları yazmıştır:

"Orta boylu hatta orta boydan biraz uzunca... Vücut narin, çehre uzunca oval, yüz hatlarından vakar ve metanet damlamakta hatta insana derin bir şey düşündüğünü tahmin ettirmektedir. Kisvesi çok sade idi, siyah çuhadan yapılmış ceket pantolon ve fes denen Türk serpuşu giymişti. ”'13

Şiblî Numanî, ile aynı bölgelere giden ve Selamlık merasimine katılarak seyahatnamesinde buna yer veren diğer bir isim Hindistan Pakistan Alt Kıtasının ileri gelen cemiyetlerinden olan Nedvetü'l-Ulema'nın âlimlerinden Hafız Abdurrahman Amritsarî'dir. 1894 yılında gerçekleştirdiği Mısır, Şam ve Anadolu seyahati ile gözlemlerini içeren seyahatnamenin ilk baskısı Mufîd ‘Âm Press tarafından Lahor'da 1908 yılında yayımlanmıştır. Amritsarî’nin seyahatinin amacı da Şiblî Numanî’de olduğu gibi İslâm ülkelerinin durumunu görmek ve İslam ülkeleri arasında koordinasyon sağlamaktır. Yaklaşık iki yıllık bir süreci kapsayan gezisi esnasında gözlemlerini Amritsar merkezli Vekil adlı Urduca gazetede yayımlamış ve gazete Alt Kıta Müslümanları tarafından ilgiyle takip edilmiştir.

Amritsarî seyahatnamesinde selamlık merasimi ile ilgili şu genel bilgileri verir:

"Türklerde selamlık uzun zamandır yapılmakta olan bir merasimdir. Her Cuma Osmanlı Devleti'nin uzak yakın farkl farklı köşelerinden gelen askerler bu törende yer alırlar. Bir seyyah için bu törenin devletin büyüklüğ̈̈nü ve ihtişamın görmek dışında herhangi bir önemi yoktur. Oysa Osmanl Devleti için önemi büyüktür. Hem askerler miskin miskin bir köşede oturmadan hareket halinde oluyorlar hem de bu merasimle Sultan ordunun durumunu görüyor. Ordu da Sultan'ın kendilerini izleme heyecaniyla her daim heyecanlı ve coşkulu kaliyor." 14

12 Şiblî Numanî, a.g.e, s.112-113.

13 Şiblî Numanî, a.g.e, s.113.

14 Movlovi Abdurrahman Amritsarî, Safarnama-i Bilad-i İslamiya, Malik Sirajuddin and Sons Publishers, Lahore 1941, s. 141. 
Amritsarî seyahatnamesinde İstanbul'a vardığında ilk arzusunun Müslümanların Halifesi Büyük Sultan Abdülhamid Han'ın Selamlık adıyla meşhur, Cuma namazı için camiye gitmesinden sonra gerçekleştirilen o muhteşem merasimi izlemek olduğunu söylemektedir. Seyahatnamesinde Sultan'ın Cuma Namazını Yıldız Sarayında bulunan ve İstanbul'a yaklaşık 3,5 km uzaklıkta Galata'nın bir parçası olan Beşiktaş’taki Hamidiye Camii’nde eda ettiğini belirtir.

Amritsarî merasime katılmasıyla ilgili süreci şu şekilde anlatır:

"Bu merasimi görme arzusuyla kendime yeni bir kıyafet aldım. Başıma da tussah ipeğinden şalı doladım. Hintli bir yolcu haysiyetiyle saat 11'e doğru Hamidiye Camiinde yerimi aldım. Tussah şalım öyle işe yaradı ki belki de nüfuzlu birinin yardımı bile bu kadar etkili olmayabilirdi. Hamidiye Camii'nde oraya buraya dolanırken bir kişi yanıma geldi. Sarığımı bağlama şeklini görüp, Urduca olarak "Hindistanlı misını??" diye sordu. Ben, "Evet" cevabını verince de hangi maksatla burada olduğumu sordu. Ben de, İslam 'ın başkentini gezme ve Sultan'l görme arzusunun beni bu diyara çektiğini söylediğimde çok memnun olarak beni caminin imamının yanına götürdü ve ona seyahatimden bahsederek selamlık merasimini izlemem için firsat verilmesi hususunda ricada bulundu. Imam Efendi kahve ikram etti ve Arapça olarak yolculuğum hakkında sorular sordu. Sonrasında etrafi iyice görebilmem için balkonda namaz kılmama izin verdi. Balkonda bulunduğun yerden çok uzakları görmeme imkân tanıyan koca koca pencereler vardı. Ayrıca camilerde selamlık merasimini izlemek için bundan daha iyi bir yer yoktu.

Sultan camiye varmak üzereyken görevliler namaz kılacak olanları caminin içine alarak kapıları kapattılar. Diğerleri selamlı merasimini göremediler. Beni İmam Efendi ile tanıştıran ve töreni böyle güzel bir yerden temaşa etmemi să̆layan kişi Bihar Eyaleti'nden Doktor Emir Ali'dir. Onun sayesinde bana balkonda yer verildi. Kendisi de benim yanimdaydl. "'15

Amritsarî selamlık merasiminin icrasını ise şu şekilde anlatmaktadır:

"Caminin etrafinda harikulade bir manzara vardı. Sultanin sarayından Hamidiye Camii'ne kadar her çeşit asker- denizci, karacl, topçu, süvari, Arap, Türk ve Kürtlerden oluşan birlikler yolun iki tarafinda üniformalarılla heybetli bir şekilde sıralanmıştı. Caminin önündeki meydanda askerler hilal şeklinde sıra olmuş Sultan'ı görme arzusuyla duvar gibi dimdik duruyorlardı. Caminin avlusu şatafatl kıyafetleriyle paşalar, yaverler ve her kademeden rütbeli kişiler ile doluydu. Sadece Sultan'ın arabası ve onun beraberindeki görevliler için yer kalmıştı. Saat 12'yi birkaç dakika geçiyordu ki askerler tarafindan meydanı çınlatan "Padişahım çok yaşa!" naraları atılmaya başlandı. Çı̆̆lıklar azalır azalmaz müezzin ezan okumaya başlad. Alçak sesle çalmakta olan bando da sustu. Bu ezan adeta Sultan'ın saraydan ayrıldığının işaretiydi. O esnada merasimin en önünde olan paşalardan oluşan uzun saf belirdi. Üzerlerinde o kadar çok nişan ve madalya asıllydı ki onların ışıltısından üniformaları görünmüyordu. Yolun iki kenarında biri diğerinin arkasında sira olarak Sultan'ın sarayından caminin kapısina kadar dizildiler. Sonradan

15 Movlovi Abdurrahman Amritsarî, a.g.e, s.134. 
gelenler önceki gelenlerin önüne doğru saf tuttular. Onlardan sonra yüksek rütbeli kişiler geçti. Doktor beye göre bu kişiler vezirlerdi. Bundan birkaç dakika sonra da Sultan'in arabası geldi. Arabanın sesi duyulur duyulmaz "Hamidiye Marşı" çalınmaya başladı. Araba baştan aşağl sarı ve yeşil renk ile bezenmişti. Sultan sade bir askeri ceket giymişti. Göğsünde rozet ya da apolet yoktu. Sadece belinde kılıcl ve başında diğer Türkler gibi fesi vardı. Karşısında Plevne Aslanı Gazi Osman Paşa oturuyordu. Araba yavaş yavaş caminin önüne, asker dizileri arasindan geçerek, sağ tarafa ulaştı. Sultan arabadan inerek camiye girdi ve padişahların namaz kılması için yapılmış olan maksure bölümüne gitti. Böylece kapı kapatıldı. Buranın sağ tarafinda da vezirlerin ve Sultanın beraberindekilerin namazlarını eda ettikleri başka bir maksure vardır."'16

Namazın tamamlanmasının ardından gerçekleştirilen askeri geçiş törenini şu sözlerle anlatmaktadır:

"Namazın tamamlanmasından sonra kendi bölmesinden çıktı. Merdiven üzerinde bütün meydanı görebileceği bir yerde durdu ve askerleri karşıladı. Askerler geçit töreni yapmaya başladılar. Acayip bir manzara vardl. İnsanlardan oluşmuş, akan bir deniz gibi görünüyordu. Alanda hazır bulunan askerlerin tamamı geçiş yaptıktan sonra Sultan arabasına bindi. Sarayına doğru yol aldi. Yolun her iki tarafinda bu askerlerin dişında askeri birlikler üniformalarını giymişler ve ileri gelen kişiler de atları üzerinde duruyorlardı." ${ }_{17}$

Amritsarî, selamlık merasiminin Avrupa'da son derece ilgiyle takip edildiğini aynı şekilde Avrupa'nın zengin ve ileri gelen kişilerinin bu azametli töreni görmeye son derece hevesli olduğunu belirtir. Bu yüzden de Sultan'ın emriyle Hamidiye Camii’nin karşısına yüksek bir alan yapıldığını ve Avrupalı seyyahlar sefarethanelerinden aldıkları izinlerle bu muhteşem gösteriyi bu alandaki pencerelerden izlediklerini ifade eder.

Amritsarî'den sonra Türklerle ilgili seyahatname yazan diğer bir isim Şeyh Abdülkadir'dir. Şeyh Abdülkadir'in yazdığg Makam-ı Hilafet ${ }^{18}$ adlı seyahatname Türklerle ilgili yazılmış diğer seyahatnameler arasında ayrıcalıklı bir yere sahiptir. Şeyh Abdülkadir gazeteci, hukuk ve siyaset adamıdır. 1895-1904 yılları arasında Lahor'da İngilizce olarak yayın yapan ilk Müslüman gazetesi olan Observer'in editörülüğünü yapmış ve Urdu dili ile yayın yapan $\mathrm{Al}$ Mahzan gazetesinde görev almıştır. 1904-1907 yılları arasında hukuk eğitimi için Londra'ya gitmiş, İstanbul'a olan seyahatini de bu süreçte gerçekleştirmiştir. Lahor'a döndükten sonra 1920 yılına kadar avukat olarak çalışmış, sonrasında siyasete atılmış ve Pencab eyaleti eğitim bakanı olarak görev yapmıştır. Özellikle İstanbul, İzmir ve Çanakkale gezilerini kapsayan Makam-ı Hilafet başlı başına Türklerle ilgili yazılmış bir eserdir ve Abdülhamid dönemine ilişkin pek çok sosyal ve kültürel bilgiler içermektedir. Aynı zamanda seyahatnamede dönemi yansitan fotoğraflar da bulunmaktadır. Şeyh Abdülkadir'in bu gezisinde kendisine Hindistan

16 Movlovi Abdurrahman Amritsarî, a.g.e, s.135-136.

17 Movlovi Abdurrahman Amritsarî, a.g.e, s.137-138.

18 Şeyh Abdulkâdir, Makâm-ı Hilâfet (Safar-ı İstanbul kē Hâlât), Mahzan Press, Dehlî 1906. 
Hilafet Hareketi'nin önderlerinden Alt Kıtanın ileri gelen hukuk adamı, yazar ve siyasetçisi olan Müşir Hüseyin Kıdvai ${ }^{19}$ de eşlik etmiştir.

Seyahatnamede 24 Ağustos 1906 tarihinde katıldığ 1 selamlık merasimi ile ilgili yazılanlar şu şekildedir:

"Bugün selamlık merasimine katılma şansı yakaladım. Burada artık merasim resmi bir tören hüviyetinde yapıllyor. Geçen sene Abdülhamid'in canına kasten bombalı saldır yapılmadan önce yabancı seyyahlar kendi sefirlerinden izin alarak bu törene katılırdı. Ancak şimdi yabancı katılımcıların sayısı çok sınırlı tutuluyor. Bizim sefirimiz (İngiltere) de bizim için izin almış ve katılmamıza izin verilmişti. Saat 11'de törenin yapılacağı yere doğru yola koyulduk. Bizim dışımızda on iki yabancı bayan da vardı. Varınca, yaklaşık bir saat yapılan hazırlıkları izledik. Devlet erkânı ve askeri birlikler sıralanmış bekliyorlardı. Geçen seneki hadiseden sonra duvar örülmüss. Hamidiye Camii'ne kadar atl süvariler sıralanmış. Sultan'ın geleceği kapının önünde de Türk, Arap ve diğer savaşçı gençler duruyordu. Askeri bando da hazır bekliyordu. Saat 12 civarı Padişah hazretlerinin arabaslyla teşrif etmekte olduğu duyuruldu. Hemen bando çalmaya başladı. 2-3 dakika içinde arabası geldi. Karşısında Serasker Mehmet Rıza Paşa oturuyordu. Araba geçerken herkes "Padişahım çok yaşa" nidaları atıyordu. Araba önümüzden geçerken biz de saygıyla selam verdik ve tebessüm ederek selamımızı aldı. Muhtemelen klyafetimizden bizim Hindistan'dan gelmiş olan iki seyyah olduğumuzu anladi... Caminin merdivenlerine varınca caminin etrafindaki asker ve devlet adamları büyük bir saygıyla selam verdi. İki eliyle selamlara karşıllk verdi ve merdivenlerden yukarı çıktı. Camiye girince Cuma namazı başladı ve namaz biter bitmez arabasına binerek dizginleri eline ald ve saraya doğru yola koyuldu. Sultan sarayın kapısından içeri girene kadar sevgi gösterisi devam etti. Harem ehli de törene iştirak etmişti ve onlar da kendi arabalarına binerek saraya doğru gittiler. "20

Sultan’ın eşkâlini şu şekilde anlatmaktadır:

"Klyafeti son derece sadeydi. Uzun bir ceket üzerine düğmeler vardı. Sakalları ne çok uzun ne çok kısa. Hiç de Avrupalıların gazetelerde tasvir ettiği gibi soluk ve pejmürde değil."21

Şeyh Abdülkadir gibi Hindistan Pakistan Alt Kıtasının ileri gelen diğer bir hukuk adamı Hamidullah Han da Selamlık merasimine katılarak gözlemlerine seyahatnamesinde yer vermiştir. Eşi ile gerçekleştirdiği Umre ziyareti sonrası İstanbul'a gelmiş, dönemin padişahı V. Mehmet Reşat ile görüşmüştür. 28 Ocak 1910 tarihinde gerçekleştirilen merasime katılan Hamidullah Han seyahatnamesinde merasimle ilgili şu bilgileri vermektedir:

"Bugün İstanbul'un caddelerinde, sokaklarında, anayollarında olağanüstü bir hareketlilik ve canlılı var. Ne tarafa giderseniz ya da ne tarafa bakarsanız insan çokluğu göze çarpar. Sokaklar kalabalı mı kalabalık. Bugün burada bu insan selinin sebebi Sultan 'in her cuma

19 Müşir Hüseyin Kıdvai’nin Osmanlı ile ilgili eserleri hakkında bkz: Müşir Hüseyin Kıdvai, Osmanlı’nın Son Dostlarl-Hint Alt Kıtasında Türk İmajı (Hazırlayan: Ahmet Zeki İzgöer), DBY Yayınları, İstanbul 2016.

20 Şeyh Abdulkâdir, a.g.e, s.248-2489

21 Şeyh Abdulḳâdir, a.g.e, s.249. 
günü önceden belirlediği bir camide Cuma namazını kılmasıdır. Bugün de günlerden cuma ve Sultan Dolmabahçe yakınlarındaki camide Cuma namazını eda edecek. Bu yüzden de şehrin yerlileri, çevre şehirlerde yaşayanlar yabancı ülkelerden gelen yolcu ve seyyahlar hepsi burada merakla bu töreni bekliyor.

Gerçekten de bu törende İstanbul'da izleyici izdihamı oluyor ve bunu görünce insanın kalbinde İslam'ın şanı, büyüklüğü ve azameti iz biraklyor... Şu an bunu izlemek için seçkin seyirci topluluğu, pek çok Avrupalı seyyah izin almış ve özel bir yerde toplanmışlar. Ordunun düzeni de görülmeye değer. Askerler saraydan camiye kadar yol boyu sira sira dizilmişler ve Sultan' 'n gelişini bekliyorlar. "22

Hamidullah Han kendisinin selamlık merasimine katılmasıyla ilgili süreci şöyle anlatır:

"Ben otelde Arap klyafeti giymiş Cuma namazı ve selamlık merasimine katılmak üzere hazırdım. Ingiliz Büyükelçiliği tarafindan benimle birlikte merasim alanına gitmesi için görevlendirilmiş bir memur geldi. Arabaya bindik ve selamlık merasiminin gerçekleştirileceği, sarayın yakınında bulunan camiye gittik. Camide Sultan'ın özel muhafizları ve Imam Efendi ile görüş̧üm. Bana kahve ikram ettiler ve hepimiz Sultan'ın gelişini beklemek üzere süvarilerin gelişinin iyi bir şekilde görülebildiği bir bölüme geçtik. Gidip oturduk. Ben de namaz kllacaktım o yüzen bu özel odada benim de bulunmama izin verdiler." 23

Sultan'ın camiye gelişi ve namazın eda edilişini ise şu cümlelerle anlatır:

“Camide Sultan'in gelmesiyle hengâme oldu. Sultan'ın arabası saraydan ayrılmış camiye doğru gelirken görülünce Türklerin milli naraları "Çok Yaşa” sesleri coşkulu kalplerle her taraftan yükseldi.

Sultan camiye girer girmez müezzin tekbir getirdi ve "Allahu Ekber" nidası duvarlarda yankılandı. Sultan ve beraberindekiler üst tarafta namaz kıldılar. Biz aşağılda imamın yakınındaydık. Son derece huşu içinde namazımızı kıldık ve hutbeyi dinledik." 24

Cuma namazından sonra Sultan V. Mehmet Reşat ile de görüşme şansı yakalayan Hamidullah Han seyahatnamesinde bu görüşmeyle ilgili şu bilgileri verir:

"Cuma Namazından sonra V. Mehmet'i görme, elini öpme şerefine nail oldum ve yirmi dakika kadar Hicaz, Hindistan ve diğer konular hakkinda sohbet ettik. Sultan benimle kimi Arapça sohbet etti kimi zaman da tercüman vasitastyla Türkçe sorular sordu. Görüşmenin sonunda hazırda bulunanlardan birine bana Kutsal emanetleri ve saray mücevherlerini göstermesi için emir verdi. O kişi de bana beni gezdirmesi için birini ayarlayacağını söyledi. Bu kişinin dışında birkaç kişi ile daha sohbet ettik. Farsça, Fransizca ve İngilizce bildikleri için Türkçe bilmiyor olmanın eksikliğini yaşamadım." ${ }^{25}$

22 Muhammad Ḥamidullah Hân (Sar Bulend Cang), Safarnama-ı Kostantiniyya, Kasim Press, Ḥaydarâbad Dekken, 1911, s. 49-50.

23 Muhammad Ḥamidullah Hân (Sar Bulend Cang), a.g.e, s. 50.

24 Muhammad Ḥamidullah Hân (Sar Bulend Cang), a.g.e, s. 51.

25 Muhạmmad Ḥamidullah Hân (Sar Bulend Cang), a.g.e, s. 52. 
Yukarıda zikredilen seyahatnameler dışında Hindistan'ın Maharaştra eyaletine bağlı Cancira bölgesi nevvabı Sir Seyid Ahmed Han, eşi Nazlı Rafia Begüm, eşinin kardeşi Atiyye Feyzi ve ileri gelen kişiler ile 1908 yılında gerçekleştirdikleri Avrupa seyahati dönüşü İstanbul'a uğramış ve bu seyahat Nazlı Rafia Begüm tarafından seyahatname olarak yayımlanmıştır. ${ }^{26}$ Seyahatnamede Nevvab Ahmed Han'ın 4 Eylül 1908 tarihinde Yıldız Camii'nde gerçekleştirilen selamlık merasimine katıldığg belirtilmişse de selamlık merasimiyle ilgili herhangi bir bilgiye yer verilmemiştir.

Sonuç olarak Alt Kıtanın ileri gelen kişileri tarafından özellikle II. Abdülhamid döneminde İstanbul'a yapılan seyahatlerle ilgili gözlemler önce Alt Kıtanın çeşitli merkezlerindeki gazetelerde yayımlanmış, sonrasında ise seyahatname olarak kaleme alınmış ve Alt Kıta Müslümanları tarafından yakından takip edilmiştir. Özellikle İslam kardeşliği vurgusu yapılan bu seyahatnamelerde eğitimden kültür ve toplum yapısına, tarihi yerlerden kadının durumuna Türklerle ilgili pek çok hususta bilgi verilmiştir. Selamlık merasimi seyahatnamelerde tüm görkem ve ihtişamıyla ele alınırken bir Müslüman olarak bu ihtişamlı manzaradan ne denli gurur duyduklarını da Alt Kitadan gelen seyyahlar seyahatnamelerinde özellikle ifade etmişlerdir.

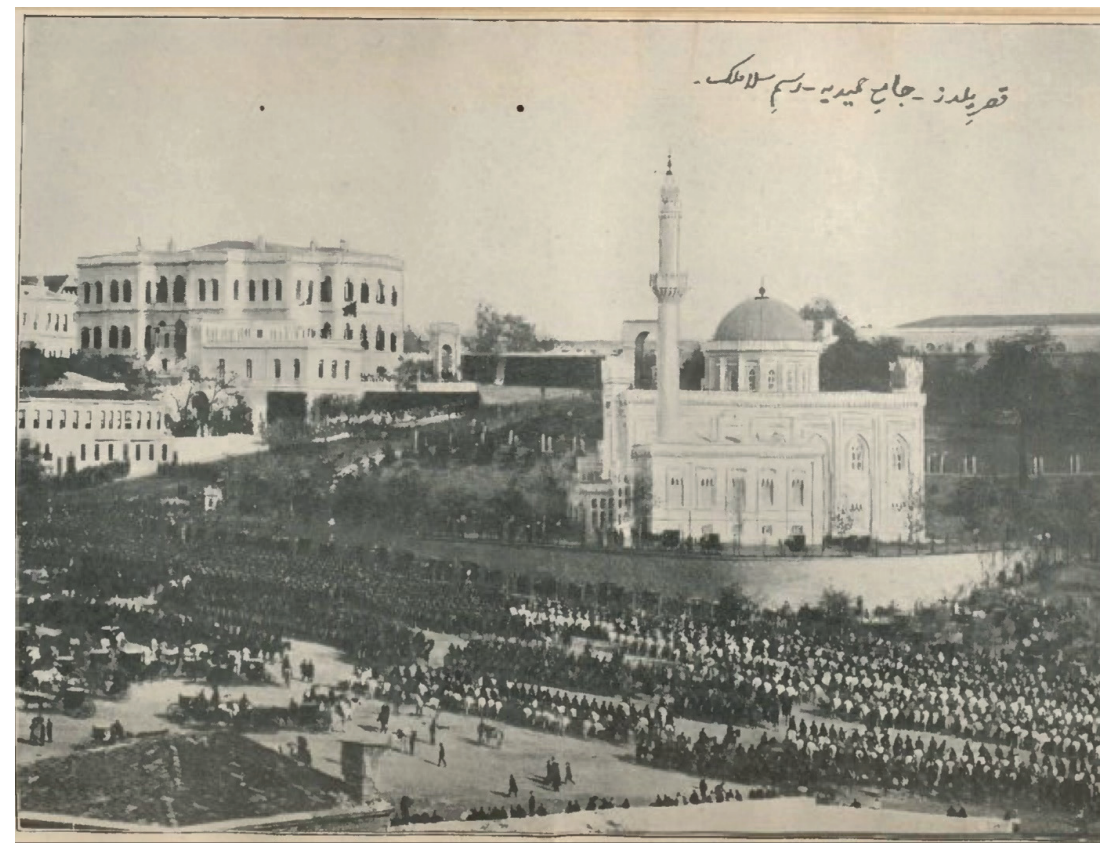

Resim 1: Şeyh Abdülkadir tarafindan yazılan Makam-ı Hilafet isimli seyahatnamede Hamidiye Camii’nde gerçekleştirilen Selamlık Merasimi.

26 Nazlı Rafia Sultan, Seyr-i Europe, Union Astim Press, Lahor 1908. 
Hakem Değerlendirmesi: Dış bağımsız.

Çıkar Çatışması: Yazar çıkar çatışması bildirmemiştir.

Finansal Destek: Yazar bu çalıșma için finansal destek almadığını beyan etmiștir.

Peer-review: Externally peer-reviewed.

Conflict of Interest: The author has no conflict of interest to declare.

Grant Support: The author declared that this study has received no financial support.

\section{Kaynakça/References}

Amritsarî, Movlovi Abdurrahman, Safarnama-i Bilad-i İslamiya, Malik Sirajuddin and Sons Publishers, Lahore 1941.

Bozdağ, İsmet, II. Abdülhamid'in Hatıra Defteri, İstanbul, Kervan Yay. İstanbul 1975.

Eraslan, Cezmi, II. Abdülhamid ve İslâm Birliği, Ötüken Yayınları, İstanbul 1992.

İpşirli, Mehmet, “Cuma Selamlı̆̆ı”, Türkiye Diyanet Vakfi İslam Ansiklopedisi, VIII, 92.

Muhammad Hamidullah Han, (Sar Bulend Cang), Safarnama-ı Kostantiniyya, Kasim Press, Haydarâbad Dekken, 1911.

Navvab Omar Han, Safarnama-i Aina-i Frang, Matba Munşi Naval Kişor, Lakhnov.

Nazlı Rafia Sultan, Seyr-i Europe, Union Astim Press, Lahor 1908.

Özcan, Azmi, (Pan-İslamizm) Osmanlı Devleti- Hindistan Müslümanlarl ve Ingiltere 1877-1924), Türkiye Diyanet Vakfı Yayınları, Ankara 1997.

Şeyh Abdulkâdir, Makâm-ı Hilâfet (Safar-ı İstanbul kē Hâlât), Mahzan Press, Dehlî 1906.

Şiblî Numanî, Anadolu-Suriye-Mısır Seyahatnamesi (Tercüme: Yusuf Karaca), Risale Yayınları, İstanbul 2002. 
